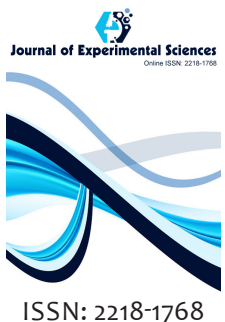

Received: December 28, 2018 Accepted: February 12, 2019 Publishe: February 19, 2019

*Corresponding Author: Manjur Shah

Email:mmanjurshah@gmail. com

\section{Pathogenic Protozoans of Grasshopper from Imphal, Manipur, India}

\author{
Indira Yumnam1, N. Mohilal', M. Manjur Shah'* \\ 'Parasitology Section, Department of Life Sciences, Manipur University Canchipur- 795003, Manipur, ²Department \\ of Biological Sciences, Yusuf Maitama Sule University, Kano, Nigeria
}

\begin{abstract}
Septate gregarines or Cephaline gregarines are a group of parasitic protozoans of Grasshopper. Eugregarines are the most common; these species inhabit the midgut though rarely pathogenic in the mid-gut, they have been reported to block the gut of the host. Those inhabiting the gastric caeca cause serious pathologies than the midgut-inhabiting species. Some of the best known genera found in Manipur are Gregarina, Phleobum, Didymophyes, Amphiplatyspora, Lepismatophila, Quadruspinospora and Quadruknobspora. The study reports the morphological details of 16species of the above genera collected from Imphal. Illustrative diagrams and photomicrographs are provided for better species identification.
\end{abstract}

KEYWORDS: Parasite, pathogenic, protozo, grasshopper

\section{INTRODUCTION}

Studies on pathogenicity of the septate gregarines upon their host could not be traced before the $20^{\text {th }}$ century. Significant contributions in the field of pathogenicity began with the very beginning of the last century. Some important contributors are Laveran and Mesnil [1], Watson [2], Grasse and Caullery [3], Haldar and Chakravarty [4], Maxwell [5], Sarkar and Chakravarty [6], Janardanan and Ramachandran [7] and Haldar and Gupta [8]. The nature of infection in host organisms caused by protozoans as well as their role in the dynamics of host population was studied by Lipa [9] besides faunistic aspects of investigation. Kundu and Haldar [10] studied on the effect of physical and chemical agents on the development of gametocysts of gregarines from coccinellid beetle. Temperature effect on formation, maturity and viability of sporocysts of ten cephaline gregarines had been shown by Patil et al. [11]. The present communication records 16 species of seven genera (Gregarina, Phleobum, Didymophyes, Amphiplatyspora, Lepismatophila, Quadruspinospora and Quadruknobspora).

\section{MATERIAL AND METHODS}

The Adults Grasshoppers were collected from various grass fields of Manipur (24_440N, 93_580E) as explained previously [15] and stained with Heidenhain's haematoxylin [12]. Gametocysts were recovered from the hind gut and placed in moist chambers ( $80 \%$ relative humidity) for sporulation [13]. Nomenclature for shapes used in this paper conforms to those of Clopton [14].

\section{RESULTS}

In the course of the present study 16 species belonging to 7 genera, 5 families and lorder are reported. Among these 16 species of Cephaline gregarines of which 2 are known species and 14 are new species.

The systematic study of the Cephaline gregarines of Grasshoppers are reported belonging to Phylum Apicomplexa are characterized by the distinctive "head" like section of the trophozoite containing the epimerite as its anterior end, protomerite segment between the epimerite and deutomerite and posterior most segment of the septate gregarine. It contains nucleus. During the lifecycle of the gregarines a trophozoite develops within a host cell into a schizont, Divides into a number of merozoites by schizogony. The merozoites are released by lysing the host cell, which in turn invade other cells and gametocytes are formed. Each gametocyte forms multiple gametes. The gametes fuse with another to form oocysts. The oocysts leave the host to be taken up by a new host. The systematic positions of the Conoidasidan parasites belonging to the class Conoidasida Levine, 1988, are provided.

$\begin{array}{ll}\text { Phylum } & \text { Apicomplexa Levine, } 1970 \\ \text { Class } & \text { Conoidasida Levine, 1988 } \\ \text { Subclass } & \text { Gregrinasina Dufour, 1828 } \\ \text { Order } & \text { Eugregarinorida Léger, 1990 } \\ \text { Suborder } & \text { Septatorina Lankester, 1885 } \\ \text { Superfamily } & \text { Gregarinidae Labbé, 1899 } \\ \text { Genus : Gregarina } & \text { Dufour, 1828 }\end{array}$

Copyright: () The authors. This article is open access and licensed under the terms of the Creative Commons Attribution License (http://creativecommons.org/licenses/by/4.0/) which permits unrestricted, use, distribution and reproduction in any medium, or format for any purpose, even commercially provided the work is properly cited. Attribution - You must give appropriate credit, provide a link to the license, and indicate if changes were made. 
The present gregarines are accommodated into this genus in having of solitary, epimerite as small knob, cysts without ducts and smooth, barrel-shaped ellipsoidal spores, caudofrontal association and dome-shaped. In present investigation altogether 6 (six) new species were discovered but here only two species are presented:

\begin{tabular}{llll}
\hline Name of the species & $\begin{array}{l}\text { Site of } \\
\text { infection }\end{array}$ & Host & Locality \\
\hline Gregarina kajipatus sp.nov. & Mid gut & Oxya hyla hyla & $\begin{array}{l}\text { Loumanbi } \\
\text { Kajipat }\end{array}$ \\
Gregarina imphaliensis sp.nov. & Mid gut & Oxya hyla hyla & Loumanbi \\
\hline
\end{tabular}

Family : Didymophyidae Léger, 1892

Genus : Phleobum (Haldar and Chakraborty, 1974) Kundu and Haldar, 1986

The gregarine under report justifies its inclusion under this genus because of the presence of globular hyaline like epimerite, sporadins in association, orange-coloured cyst and ovoidal oocysts, orbicular to ellipsoidal nucleus. In present study, 3 (three) new species are discovered, two species are mentioned below:

\begin{tabular}{llll}
\hline Name of the species & $\begin{array}{l}\text { Site of } \\
\text { infection }\end{array}$ & Host & Locality \\
\hline Phleobum loumanbiasis sp.nov. & Mid gut & Oxya hyla hyla & Loumanbi \\
Phleobum manipurensis sp.nov. & Mid gut & Oxya hyla hyla & Loumanbi \\
\hline
\end{tabular}

Family : Didymophyidae Léger, 1892

Genus : Didymophyes Von Stein, 1848

In the presence of sporadins in association and satellite without septum the present gregarine is placed under the genus Didymophyes Von Stein, 1848 under the family Didymophyidae Léger, 1892. During the present investigation, 3 (three) new species were obtained, here one species was described.

\begin{tabular}{llll}
\hline Name of the species & $\begin{array}{l}\text { Site of } \\
\text { infection }\end{array}$ & Host & Locality \\
\hline $\begin{array}{l}\text { Didymophyes triangulogametus } \\
\text { sp.nov. }\end{array}$ & Mid gut & Oxya hyla hyla & Kajipat \\
\hline
\end{tabular}

Superfamily : Stenophoridae Levine, 1984

Family : Amphiplatysporidae Kundu and Haldar, 1984

Genus : Amphiplatyspora Kundu and Haldar, 1984

Trophozoite without an epimerite; sporadins solitary; gametocyst ovoidal with a prominent ectocyst, dehiscing by simple rupture; and spores cylindrical extruded, with flat, plate-like thickenings on both poles. As such, it can at once be placed in the genus Amphiplatyspora, Kundu and Haldar, 1984 under the family Stenophoridae Léger and Duboscq, 1904. During the study on the cephaline gregarine of insect pests, one gregarine belonging to the genus Amphipltyspora was obtained named as Amphipltysporastriatafirst record from Manipur.

\begin{tabular}{llll}
\hline Name of the species & $\begin{array}{l}\text { Site of } \\
\text { infection }\end{array}$ & Host & Locality \\
\hline $\begin{array}{l}\text { Amphiplatyspora striata } \\
\text { Kundu and Haldar, 1984 }\end{array}$ & Mid gut & Chondracis rosea & Kajipat \\
\hline
\end{tabular}

Family : Stylocephalidae Ellis, 1912

Genus : Lepismatophila Adams and Travis, 1935

In having solitary sporadins, epimerite a simple symmetrical knob, protomerite present throughout trophozoite stage, cyst without ducts dehiscence by simple rupture and spores in uncoiling chains, ellipsoidal, boat shaped, without any filamentous process.In the present investigation, the cephaline gregarine obtained from Chondracis rosea (Order: Orthopteran) collected from Kajipat, Imphal-east, Manipur was found to be Lepismatophila cruszi and redescribed.

\begin{tabular}{llll}
\hline Name of the species & $\begin{array}{l}\text { Site of } \\
\text { infection }\end{array}$ & Host & Locality \\
\hline $\begin{array}{l}\text { Lepismatophila cruszi } \\
\text { Kundu and Haldar, 1984 }\end{array}$ & Mid gut & Chondracis rosea & Kajipat \\
\hline
\end{tabular}

Family : Actinocephalidae Léger, 1892

Genus : Quadruspinospora Sarkar and Chakravarty, 1969

Presence of epimerite with stumpy, digitiform processes, solitary sporadins, dehiscence of cyst by simple rupture and spherical spores with spines confirm inclusion of the gregarine under the genus Quadruspinospora Sarkar and Chakravarty, 1969. In the present work only one species had been described.

\begin{tabular}{llll}
\hline Name of the species & $\begin{array}{l}\text { Site of } \\
\text { infection }\end{array}$ & Host & Locality \\
\hline Quadruspinospora oxyae sp.nov. & Mid gut & Oxya hyla hyla & Loumanbi \\
\hline
\end{tabular}

Genus : Qradruknobospora Chatterjee and Haldar, 2003

The characters like presence of solitary sporadins, thick-walled spherical gametocysts dehiscing by simple rupture, oval oocyst with knob like structure, epimerite having the shape of cauliflower justify the inclusion of the gregarine under the genus Quadruknobospora Chatterjee and Haldar, 2003.In course of the present investigation, only one species was discovered from the valley districts of Manipur.

\begin{tabular}{llll}
\hline Name of the species & $\begin{array}{l}\text { Site of } \\
\text { infection }\end{array}$ & Host & Locality \\
\hline $\begin{array}{l}\text { Quadruknobosporaorthopteraensis } \\
\text { sp.nov. }\end{array}$ & Mid gut & Oxya hyla hyla & Loumanbi \\
\hline
\end{tabular}

\section{CONCLUSION}

Gregarines is the ubiquitous and taxonomically diverse of all parasites, infecting a wide range of invertebrate hosts, including arthropod. During the present work have been found to be widely present in Grasshoppers and are able to contribute 14 new species to science and 2 species as record from Manipur. 


\section{ACKNOWLEDGEMENTS}

The Authors acknowledge to laboratory facilities provided by the Head, Department of Life Sciences and Co-ordinator, Centre of Advanced Studies in Life Sciences, Manipur University and the first Author acknowledge the financial assistance provided by Manipur University for Ph.D. work.

\section{AUTHORS CONTRIBUTION}

The first author conducted the work, the second author planned the work and the third author conducted analysis and presentation of the result.

\section{REFERENCES}

1. Laveran, M., and Mesnil. Sur quelques particularités de Í evolution dŭne Grégarine et la reaction de la cellule hóte. C. R. Soc. Biol.1990;52: 554-557.

2. Watson, M.E. Studies on gregarines. III. Biol.Monogr. 1916; 2:1- 258.

3. Grassé, P.P., and Caullery, M.C. Traité de zoologie: anatomie, systématique, biologie. 1953.pp.804

4. Haldar, D.P., and Chakraborty, N. Morphology and life history of cephaline gregarine, Quadruspinospora chakrvartyei, Chakraborty and Haldar (Protozoa: Sporozoa).Geobios. 1975;2: 104-106.

5. Maxwell, R.D. Gregarines and Haemogregarines. In: Parasitic
Protozoa. III. Academic Press, INC. (London) Ltd. 1977;1-32.

6. Sarkar, N. K., and Chakravarty, M. Gregarines (Protozoa: Sporozoa) from insects. I. New cephaline gregarines of the family Actinocephalidae. Proc. Zool. Soc. Calcutta. 1969;22:17-29.

7. Janardanan, K.P. and Ramachandran, P. Studies on a new cephaline gregarine, Stenoductus trigoniuli n. sp. with a note on its cytopathology, Arch. Protistenk. 1982; 125: 249-256.

8. Haldar, D.P and Gupta, S. Steinina palorusi n. sp., a new species of septate gregarines (Apicomplexa: Sporozoea) from the larva of a tenebrionid beetle. Archiv fu"rProtistenk. 1987;133:135-144.

9. Lipa, J.J. Studies on gregarines (Gregarinomorpha) of arthropods in Poland. Acta. Protozool. 1967;5(8): 97-179.

10. Kundu, T.K., and Haldar, D.P. Observations on Quadruhyaiodiscus gallerucidae gen. nov., sp. nov. (Apicomplexa: Sporozoxa) from a chrysomelid beetle, Gallerucida bicelor. Arch. Protistenk. 1984;128: 327-334.

11. Patil, C.C., Amoji, S. D. and Neelgund, Y.F. Effect of temperature on the formation of sporocysts and their viability. Arch. Protistenk. 1983; 127:181-187.

12. Kudo. Studies on Nyctanthes arbor-tristis Linn. Proc. Indian Sci, Congr Assn. Part III. Chandigarh. 1966.

13. Sprague, V. Studies on Gregarina blattarum with particular reference in the chromosome cycle. Univ. III. Biol Monogr. 1941;18(2):5-57.

14. Clopton, R.E. Standard nomenclature and metrics of plane shapes for use in gregarine taxonomy. Comp Parasitol. 2004;71(130):140. doi:10.1654/4151.

15. Yumnam I, Mohilal N. A new species of Quadruspinospora Sarkar and Chakravarty, 1969 (Apicomplexa: Conoidasida) from Orthopteran Insects of Manipur, India. Journal of Parasitic Diseases. 2017:41(2):313-7. 